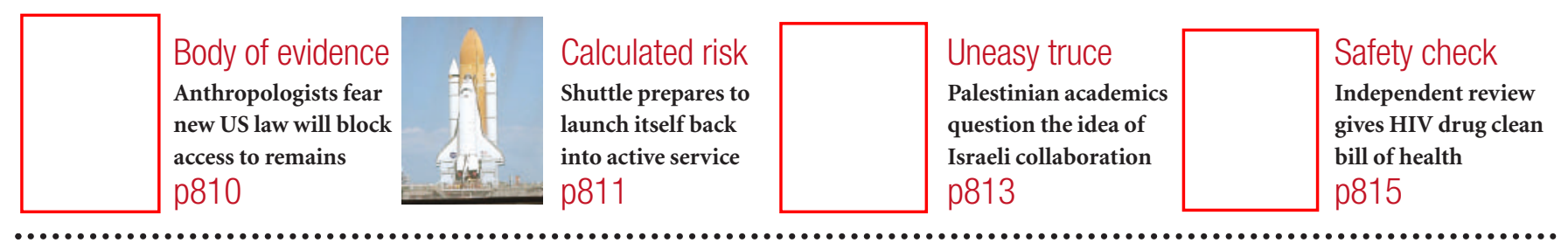

\title{
Divergent local laws threaten to stifle Europe's stem-cell project
}

\section{Quirin Schiermeier, Munich}

A high-profile European collaboration in human embryonic stem-cell research is showing signs of trouble before the first pipette has even been unpacked.

Scientists believe that the project could become the continent's most ambitious and promising collaboration in the field so far. But they fear it may be broken up or delayed because of the muddled legal situation surrounding stem-cell research in the European Union (EU).

As Nature went to press, representatives of the $25 \mathrm{EU}$ member states were meeting in Brussels to decide whether to approve a $€ 540$ million (US\$700-million) package of research projects. The European Commission has already earmarked these for funding under the current Framework Programme on research.

The $€ 12$-million stem-cell project is by far the most controversial item on the list. The team behind it includes applicants from Britain, Germany, Sweden, Finland, Italy and France, who plan jointly to investigate the biomedical potential of human embryonic stem cells.

Because such cells can transform into almost any cell type, the hope is that one day they will provide powerful therapies for a wide range of serious conditions, from heart disease to Parkinson's. But isolating them raises ethical concerns, because it requires the destruction of human embryos.

The problem facing the meeting in Brussels is that although a few EU countries,

\section{IMAGE \\ UNAVAILABLE FOR COPYRIGHT REASONS}

Ball of contention: Europe remains divided over the ethics of human embryonic stem-cell research.

such as Britain and Sweden, have adopted relatively liberal stem-cell rules, the situation elsewhere is either unclear or markedly more restrictive. Italy, for example, faces a referendum in June about the use of human embryonic stem cells in research, something that Prime Minister Silvio Berlusconi's rightwing government does not support.

And in Germany, most research involving human embryos is illegal, carrying a penalty of up to three years in jail. The use of imported embryonic stem-cell lines created before January 2002 is allowed, provided there is no other way to do the research.

The planned project would involve recent cell lines. So the fear is that EU representatives of countries that don't allow such work will delay the project, or pull out altogether.

"I don't expect it will go smoothly," says
Austin Smith, a stem-cell researcher at the University of Edinburgh, UK, and coordinator of EuroStemCell, the only existing EU-funded stem-cell project, which so far has used mainly adult or mouse cells. "It is still possible that the whole project will be challenged."

Oliver Brüstle, a neuroscientist at the University of Bonn in Germany, hopes to be part of the new collaboration and also appeals to European governments not to blockit."Intellectually, Europe is $100 \%$ competitive with the United States," he says. "But it is essential that the strongest groups are able to share their findings and allocate research according to their respective strengths."

Brüstle believes that it would be possible to divide the project up so that German or Italian participants wouldn't come into conflict with their national laws, even when working with colleagues abroad.

Whether or not the proposal pans out, stem-cell research will be overshadowed by a deep political divide between the appointed European Commission and the elected European Parliament. The parliament, traditionally more concerned about the views of individual member countries, recently passed a resolution saying that human embryonic stem-cell research should not get European funding, but be financed from the budgets of countries where such research is legal.

But the commission did not mention this when it announced plans to double the budget for the EU's next Framework Programme on research from 2007 (see page 815).

\section{US health officials rally behind bid to relax rules on embryo research}

Top officials at the US National Institutes of Health (NIH) have made a pitch for the country's lawmakers to loosen rules that govern federal funding for human embryonic stem-cell research.

The officials lobbied senators who control the agency's budget at a hearing on 6 April. The current policy, set out by President George Bush, prevents scientists from using federal funds to do research on human embryonic stem-cell lines derived after 9 August 2001.

"Access to more cells is seen by scientists as very important to their progress," $\mathrm{NIH}$ director Elias Zerhouni told the hearing.

In written testimony, other $\mathrm{NIH}$ leaders were

more forceful. "The state of the science is evolving very rapidly and limitations of the president's policy are becoming more apparent," wrote James Battey, director of the National Institute on Deafness and Other Communication Disorders and former head of the NIH Stem Cell Task Force.

Zerhouni has said in the past that scientists should exhaust all the work they can possibly do on permitted stem-cell lines before revisiting the Bush policy. He has also pointed out that the policy is based not only on science, but on ethics and morality. At the hearing he was careful to state that he did not advocate overturning the policy.

But momentum has been building in Congress to do just that. Scientists have complained loudly that too few lines are available, and that they are contaminated by mouse cells. Support has been growing in the Senate to overturn the Bush rules, and leaders in the House of Representatives last month indicated that they may also be open to revisiting the policy (see Nature 434, 548; 2005). Erika Check, Washington 